\title{
Assessment of Biogenic Amines in some Fishes at Kalyobia Governorate S.M. l-Khabaz ${ }^{1}$ H.M.Ibrahim ${ }^{2}$ and R.A.Amin ${ }^{2}$ \\ ${ }^{1}$ Director of Veterinary Medicine Qalyubiya,Egypt \\ ${ }^{2}$ Food Hygeine Control Dept., Faculty of Veterinary Medicine, Benha Univ., Benha, Egypt
}

\begin{abstract}
A grand total of 90 random samples of fresh fish samples represented by Nile fish(Oreochromis niloticus, Clarias lazera \& Bagrus bayad)(15 of each) and marine fish(Sardine, Saurus, Pagrus)(15 of each) were collected randomly from different fish markets in Benha, Kalyobia governorate for determination of histamine and putrescine using High Performance Liquid Chromatography (HPLC). The results showed that 80\%, 86.67\% and $100 \%$ of Nile fish samples were positive for the presence of histamine residues for Bagrus bayad, Tilapianiloticus and Clarias lazera, respectively. Concerning to marine fish, the positive samples for histamine in samples from Pagrus, Saurus and Sardine were 93.33\%, 100\% and 100\%, respectively. While, concerning to putrescine residues in Nile fish, the positive samples were 53.33\%, 60\% and $80 \%$ in Bagrus bayad, Tilapia niloticus and Clarias lazera, respectively; and in marine fish $66.67 \%, 80 \%$ and $86.67 \%$.in Pagrus, Saurus and Sardine, respectively. The public health significance of histamine and putrescine residues in fish and some recommendations to control their presence were discussed.
\end{abstract}

Keywords: Fish meat, Fresh fish, Histamine, Putrescine, HPLC .

\section{Introduction}

Fish meat is considered one of the most important nutrients, as they are easily digestible characterized by quality and taste and excellence in food conversion rate on many of the other types of meat in addition to the short production cycle and the low cost of breeding and feeding [1].Fish meat share in solving the shortage in animal protein requirement; it is the most important single source of high-quality protein, providing nearly $16 \%$ of the animal protein consumed by the world's population [2].Biogenic amines present in a wide range of food products including fish products [3]. The content of biogenic amines in foods can be considered as quality marker which determines the poor quality of raw materials. Accordingly, the concentrations of biogenic amines in any food of animal origin can be used as chemical indicators of thefreshness of animal origin products [4]. Excessive consumption of these amines can be of health concern through their actions on nervous, gastric and intestinal systems and blood pressure causing degrees of diseases [5]. Biogenic amines production in fish is affected by availability of free amino acids, presence of microorganisms that can decarboxylase amino acids and favorable conditions for their growth [6]. Histamine occurs in all types of food particularly fish. Histamine can be an indicator of defective hygiene during preparation or storage of the food[7] . Putrescine is one of the most common biogenic amines in food. The excessive levels ofputrescine in food may lead to alimentary poisoning [8]. Putrescine and cadaverine can react with nitrite forming heterocyclic carcinogenic nitrosamine, nitrosopyrrolidine and nitrosopiperidine [9].

Therefore, the aim of the current study is to determine the level of histamine and putrescine residues in Nile and marine fish by using high performance liquid chromatography (HPLC).

\section{Material and methods \\ 2.1 Collection of samples}

A grand total of nintey random samples of fresh fish samples represented by Nile fish (Oreochromis niloticus, Clarias lazera \& Bagrus bayad, 15 of each) and marine fish (Sardine, Saurus\& Pagrus, 15 of each) were collected from different fish markets in Benha, Kalyobia governorate. The collected samples were packed separately in sterile polyethylene bag and transferred directly to the laboratory without delay for determination of their biogenic amine residues.

\subsection{Determination of biogenic amines by using HPLC}

Histamine and putrescine were determined in all examined samples according to the protocol recommended by Krause et al. (1995) and Pinho et al. (2001).

\section{Extraction of samples}

Twenty five grams of each sample was blended with $125 \mathrm{ml}$ of $5 \%$ Trichloro acetic acid (TCA) for 3 min using a warning blender then filtration was achieved using filter paper Whatman No1. Thus, 10 $\mathrm{ml}$ of the filtrate were transferred into a suitable glass tube with $\quad 4 \mathrm{~g} \mathrm{NaCl}$ and $1 \mathrm{ml}$ of $50 \%$ $\mathrm{NaOH}$. The filtrate was extracted three times $(2 \mathrm{~min}$ each) by using $5 \mathrm{ml} \mathrm{n}$-butanol: chloroform $(1: 1 \mathrm{v} / \mathrm{v})$ and the upper clear layer was transferred to $100 \mathrm{ml}$ separating funnel by using disposable Pasteur pipette. To combine the organic extracts (upper layer), $15 \mathrm{ml}$ of $\mathrm{n}$-heptane was added in separating funnel and extracted three times with $1.0 \mathrm{ml}$ portions of $0.2 \mathrm{NHCl}$, the $\mathrm{HCl}$ layer was collected 
in a glass Stoppard tube. Solution was evaporated just to dryness using water bath at $95^{\circ} \mathrm{C}$ with aid of a gentle current of air. About $0.5 \mathrm{ml}$ of saturated $\mathrm{NaHCO} 3$ solution was added to the residue of the sample extract (or the standard). Vial was stoppered and carefully mixed to prevent loss- due to spattering. Carefully, $1.0 \mathrm{ml}$ dansyl chloride solution was added and mixed thoroughly using vortex mixer. The reaction mixture was incubated at $55^{\circ} \mathrm{C}$ for $45 \mathrm{~min}$. About $10 \mathrm{ml}$ of distilled water were added to the reaction mixture, then vial was stoppered and shaked vigorously using vortex mixer, the extraction of dansylated biogenic amines was carried out using $5 \mathrm{ml}$ of diethyl ether for 3times again vial was stoppered, shaked for 11.0 min and the ether layers were collected in a culture tube using disposable Pasteur pipette. The combined ether extracts were carefully evaporated at $35^{\circ} \mathrm{C}$ in dry bath with aid of current air. The obtained dry material was dissolved in $1 \mathrm{ml}$ methanol and $10 \mu$ l were injected in HPLC.

\section{Statistical analysis}

The obtained results were statistically evaluated by application of Analysis of Variance (ANOVA) test [10].

\subsection{Results and discussion}

It is evident from the results recorded in table (1) that the histamine levels were varied in Nile fish from 1.3 to 29.7 with an average of $13.75+1.14$ for Bagrus bayad, 2.8 to 41.5 with an average of 22.68 +1.96 for Tilapia niloticus, 4.0 to 62.1 with an average of $37.14+2.79$ for Clarias lazera. However, in marine fish, the histamine levels were varied from 3.4 to 47.9 with an average of $28.51+$ 1.83 , from 6.2 to 65.1 with an average of $46.09+$ 3.25 and from 7.8 to 91.6 with an average of 59.84 + 3.42 for Pagrus, Saurus and Sardine, respectively.

The results achieved in table (2) declared the acceptability of the examined samples based on their levels of histamine according to [11] which stated their maximum permissible limit of histamine was $20 \mathrm{mg} \%$. Therefore, the number of the unaccepted samples of Nile fish were $3(20 \%)$ in Bagrus bayad, 4 (26.67\%) in Tilapia niloticus and $7(46.67 \%)$ in Clarias lazera, while the number of the unaccepted samples of marine fish were 6 (40\%), 8 (53.33\%) and $9(60 \%)$ in Pagrus, Saurus and Sardine respectively.

Table (3) revealed that the concentrations of putrescine $(\mathrm{mg} \%)$ in the examined samples were ranged from 1.0 to 22.1 with a mean value of $8.83 \pm$ 0.72 for Bagrus bayad,1.0 to 28.6 with a mean value of $11.29 \pm 1.05$ for Tilapia niloticus and 2.2 to 36.9 with a mean value of $20.53 \pm 1.66$ for Clarias lazera. While in marine fish, putrescine concentration ( $\mathrm{mg} \%)$ in the examined samples were ranged from 1.9 to 30.5 with a mean value of $17.15 \pm 1.45,3.1$ to 39.7 with a mean value of $23.70 \pm 1.89$ and 4.5 to 46.4 with a mean value of $27.98 \pm 2.12$ for Pagrus, Saurus and Sardine respectively.

The results achieved in table (4) declared the acceptability of the examined fish samples based on their levels of putrescine according to[11] which stipulated their maximum permissible limit in fish samples was $20 \mathrm{mg} \%$. Therefore, the number of the unaccepted samples of Nile fish was $2(13.33 \%)$ in Bagrus bayad, 2 (13.33\%) in Tilapia niloticus and 4 $(26.67 \%)$ in Clarias lazera. While, in marine fish the number of the unaccepted samples were 3 (20\%), 5 (33.33\%) and 6 (40\%) in Pagrus, Saurus and Sardine respectively.

From the obtained results, the collected fish samples (Nile and marine fish) contained high levels of toxic biogenic amines (histamine and putrescine). The present results are lower than those reported by [12] who detect high histamine level in Sardine samples exceeding $50 \mathrm{ppm}$. Also the present results are lower than those reported by [13] who detect high histamine level (2350 ppm) in Sardine samples after 24 hours at ambient temperature and similar levels after 8 days storage in ice. Histamine alone may not cause toxicity at a low level, but the presence of other biogenic amines such as putrescine and cadaverine, at concentrations 5 times higher than histamine, enhance the toxicity of histamine through the inhibition of histamine oxidizing enzymes [14]. Histamine poisoning has a short incubation period, ranging from minutes to a few hours after ingestion with syptoms of headache, facial flushing and sweating, rash and itching, nausea, vomiting, diarrhea and heart palpitations [15]. The present results came inaccordance with those reported by [16] who found that putrescine was detected in all tested samples of fish commonly consumed in southern China within a range of $(0.19-45.16 \mathrm{mg} / \mathrm{kg})$. The present results came in agreement with Bunka et al. (2013) who reported that putrescine was the most abundant biogenic amine observed in raw fresh water and sea fish samples, and its concentrations up to $10 \mathrm{mg} / \mathrm{kg}$ and between 10 and $100 \mathrm{mg} / \mathrm{kg}$ were recorded in 26 and 69 samples, respectively. Higher levels were detected by [13] who found that putrescine accumulated to level of $300 \mathrm{ppm}$ in sardine after 24 hours at ambient temperature and similar levels after 8 days on ice.

The present study allows confirming the bad hazard using of biogenic amines in fish. Accordingly, the concerned authorities must take extra efforts for corrective methods of decreasing or even elimination their levels for solving the problem of such residues in fish meat. 
Table (1) Statistical Statistical analytical results of histamine levels $(\mathrm{mg} / \mathrm{kg})$ in the examined samples of Nile and marine fish $(n=15)$.

\begin{tabular}{lccc}
\hline Fish species & Min. & Max. & Mean \pm S.E* \\
\hline Nile Fish: & & & $13.75 \pm 1.14$ \\
Bagrus bayad & 1.3 & 29.7 & $22.68 \pm 1.96$ \\
Tilapia niloticus & 2.8 & 41.5 & $37.14 \pm 2.79$ \\
Clarias lazera & 4.0 & 62.1 & \\
Marine Fish: & & & $28.51 \pm 1.83$ \\
Pagrus & 3.4 & 47.9 & $46.09 \pm 3.25$ \\
Saurus & 6.2 & 65.1 & $59.84 \pm 3.42$ \\
Sardine & 7.8 & 91.6 & \\
\hline
\end{tabular}

$* \mathbf{S . E}=$ Standard Error of the mean.

Table (2) Acceptability of the examined samples of fish based on their levels of histamine $(\mathrm{n}=15)$.

\begin{tabular}{lccccc}
\hline \multirow{2}{*}{ Fish species } & $\begin{array}{c}\text { Maximum Permissible Limit } \\
(\mathbf{m g} \%)\end{array}$ & \multicolumn{2}{c}{ Positive samples } & \multicolumn{2}{c}{ Unaccepted Samples } \\
\cline { 3 - 5 } & & No. & \% & No. & \% \\
\hline Nile Fish: & 20 & 12 & 80 & 3 & 20 \\
Bagrusbayad & 20 & 13 & 86.67 & 4 & 26.67 \\
Tilapia niloticus & 20 & 15 & 100 & 7 & 46.67 \\
Clarias lazera & 20 & & & & 40 \\
Marine Fish: & 20 & 14 & 93.33 & 6 & 53.33 \\
Pagrus & 20 & 15 & 100 & 8 & 60 \\
Saurus & & 15 & 100 & 9 & \\
Sardine & & & & &
\end{tabular}

* Maximum Residual Limit stipulated by Egyptian Organization for Standardization "EOS" (2005).

Table (3) Statistical Statistical analytical results of putrescinelevels ( $\mathrm{mg} / \mathrm{kg}$ ) in the examined samples of Nile and marine fish $(n=15)$.

\begin{tabular}{lccc}
\hline Fish species & Min. & Max. & Mean \pm S.E* \\
\hline Nile Fish: & & & $8.83 \pm 0.72$ \\
Bagrusbayad & 1.0 & 22.1 & $11.29 \pm 1.05$ \\
Tilapia niloticus & 1.0 & 28.6 & $20.53 \pm 1.66$ \\
Clarias lazera & 2.2 & 36.9 & \\
Marine Fish: & & & $17.15 \pm 1.45$ \\
Pagrus & 1.9 & 30.5 & $23.70 \pm 1.89$ \\
Saurus & 3.1 & 39.7 & $27.98 \pm 2.12$ \\
Sardine & 4.5 & 46.4 & \\
\hline
\end{tabular}

$* \mathbf{S} . \mathbf{E}=$ Standard Error of the mean.

Table (4) Acceptability of the examined samples of fish based on their levels of putrescine $(n=15)$.

\begin{tabular}{lccccc}
\hline \multirow{2}{*}{ Fish species } & \multicolumn{2}{c}{$\begin{array}{c}\text { Maximum Permissible } \\
\text { Limit }\end{array}$} & \multicolumn{2}{c}{ Positive samples } & \multicolumn{2}{c}{ Unaccepted Samples } \\
\cline { 5 - 7 } & & No. & $\%$ & No. & $\%$ \\
\hline Nile Fish: & 20 & 8 & 53.33 & 2 & 13.33 \\
Bagrusbayad & 20 & 9 & 60 & 2 & 13.33 \\
Tilapia niloticus & 20 & 12 & 80 & 4 & 26.67 \\
Clarias lazera & & & & \\
Marine Fish: & 20 & 10 & 66.67 & 3 & 20 \\
Pagrus & 20 & 12 & 80 & 5 & 33.33 \\
Saurus & 20 & 13 & 86.67 & 6 & 40 \\
Sardine & & & & & \\
\hline
\end{tabular}

* Maximum Residual Limit stipulated by Egyptian Organization for Standardization "EOS"(2005). 


\section{References}

[1] N.A. Abdel Ghany, Studies on toxicbiological behavior of extraculture toxic substances of toxogenic fungi from freshwater fish. Ph.D. Thesis. (Microbiology). Faculty of Veterinary Medicine, Zagazig University, 2003.

[2] FAO Review 'of the State of World Aquaculture. FAO Fisheries Circular No. 886, Rev. 1. Rome, Italy.

[3] B.Brink, T.;Damink, C.;Joosten, H.M.L.J. and Huis in't Veld, J.H.J. Occurrence and formation of biologically active amines in foods. International J. Food Microbial. Vol .11(1) ,pp. 73-84,1990

[4] Allen, G.;Green, D.;Bolton, G.;Jaykus, L. and Cope, G. (2004):Detection and identification of histamine producing bacteria associated with harvesting and primary processing of Tuna in north Carolina. J. Food Protect., Vol67,pp.7981,1997

[5] G.Suzzi, and Gardini, F. Biogenicamines in dry fermented sausages: a review. Int. J. Food Microbiol., Vol.54, pp. 88-41,2003

[6] El-Mossalami, H.H.A. and El-Agizy, S. A. E. Hazard of some toxic biogenic amines and improvement the quality of some fish and fish products in Alexandria city. $\mathbf{J}$. Beni-Suef Veterinary Medicine,Vol.15,pp.83-90,2005

[7] P.Blanco,F.;Montana Miguelez.J. de. Ia and Simal Gandara, J.Histamine in foods Recent Research Developments in Agricultural \& food chemistry.Vol.5, pp.201-216,2005

[8] Wunderlichova, L. Bunkova, L. Koutny, M. Jancova, J. and Bunka, F. Formation, degradation, and detoxification of putrescine by food borne bacteria: a review, Comprehensive Reviews in Food Science and Food Safety. J. Institute of
Food Technologists, Vol.13,pp.10121030,2014

[9] S. Santos, M.H. Biogenic amines: their importance in foods. Int. J. Food Microbiol.,Vol.29(2),pp.213-231,1996

[10] Feldman, D. Hoffman, R. and Simpson, J. The solution for data analysis and presentation graphics. 2nd Ed., Abacus Lancripts, Inc., Barkeley, CA, USA. 2003

[11] Egyptian Organization for Standardization and Quality "E.O.S." Detection of poisons and control. Report Vol.1796.2005

[12] T. Sato, M. Zhang, H. Yamaguchi,T. and Nakano.T. A survey of histamine content in seafood sold in markets of nine countries. J.Food Control.pp. $1: 3,2010$

[13] Abobouchi, L.Afilal, M.E.Benobdeljelil, H. and Busta,F.FQuantitative changes in bacteria, amino acids and biogenic amines in sardine stored at ambient temperature $\left(25-28^{\circ} \mathrm{C}\right)$ and in ice. Int. J. Food Science and techno., Vol.26(3),pp.297-306.1991

[14] J. Emborg, and Dalgaard,P. Formation of histamine and biogenic amines in coldsmoked tuna: an investigation of psychrotolerant bacteria from samples implicated in cases of histamine fish poisoning. J Food Prot.;Vol. 69,pp. 897-906,.2006

[15] K. Becker, K. Southwick, J. Reardon, R. Berg, and Mac Cormack, J. N. Histamine poisoning associated with eating tuna burgers. Jama - Journal of the American Medical Association, Vol. 285 (10), pp. 1327-1330, 2001

[16] H,Zhai, Yang, X. Li, L. Xia, G. Cen, J. Huang, H. and Hao, S. Biogenic amines in commercial fish and fish products sold in southern china. Food ControlVol. 25, pp. 303-308,. 2012 